\title{
Assessment of Surface Water Quality of Chimdi Lake of Sunsari District, Nepal
}

\author{
Bishnu Dev Das \\ Department of Botany, Mahendra Morang Aadarsh Multiple Campus (Tribhuvan University), Biratnagar, Nepal
}

Email address:

bishnudevnp@gmail.com

\section{To cite this article:}

Bishnu Dev Das. Assessment of Surface Water Quality of Chimdi Lake of Sunsari District, Nepal. International Journal of Natural Resource Ecology and Management. Vol. 2, No. 2, 2017, pp. 20-23. doi: 10.11648/j.ijnrem.20170202.11

Received: January 18, 2017; Accepted: February 6, 2017; Published: March 10, 2017

\begin{abstract}
Chimdi Lake has ecological significance as it has been a home for several associated biodiversities. A study was carried out to investigate the pollution status by analyzing some important physicochemical parameters of Chimdi Lake. The parameters analyzed were ambient temperature water temperature, Turbidity, Total Dissolved Solid (TDS), Total Suspended Solid (TSS), Conductivity, Hydrogen- ion-concentration ( $\mathrm{pH}$ ), Dissolved Oxygen (DO), Total hardness (TH), Chloride, Nitrate - Nitrogen $\left(\mathrm{NO}_{3}-\mathrm{N}\right)$, Phosphate- phosphorus ( $\left.\mathrm{PO}_{4}-\mathrm{P}\right)$, Chemical Oxygen Demand (COD), Biological Oxygen Demand (BOD) and fecal coliform. On the basis of pollution status found, the water of the lake was unfit for drinking purposes.
\end{abstract}

Keywords: Chimdi Lake, Water Quality, Microbiological, Pollution Status, Nepal

\section{Introduction}

Water is the most vital natural resource of our environment. Functioning of biosphere is totally dependent upon water and its quality. Water as environmental factor which maintains the integrity of the aquatic ecosystem [1]. Changes in water quality are reflected in its physical, biological, and chemical conditions; and these in turn are influenced by physical and anthropogenic activities [2]. Lakes are the important habitats for the study of ecosystem dynamics: interactions among biological, chemical and physical processes are frequently either quantitatively or qualitatively distinct from those on land or in air. Most of the surface waters are heavily loaded with phosphate and nitrate [3].

A Lake ecosystem consists of the physical, chemical and biological properties contained within these water bodies. There are several medium and small lakes in the country which cover, 5000 hectares. These have different geological origins and can be classified into glacial, ox-bow, and tectonic categories [4]. Mostly ox-bow lakes and ponds occur in the Terai plain of Nepal and they are eutrophic. In many places lakes/ponds have converted into marshes (Ghols) or swamps due to siltation and plant succession [4]. The movement of chemicals, sediments, detritus, and of many organisms, is typically unidirectional from the watershed to the lake, but fish may migrate upstream, and aquatic insects may emerge and disperse on to land. A lake and its watershed are often considered to be a single ecosystem [5]. Water quality in aquatic system is important because it maintains the ecological processes that support biodiversity. However, declining water quality due to environmental perturbations threatens the stability of biotic integrity and therefore, hinders the ecosystem services and functions of aquatic ecosystems [6].

Lake water is a source of drinking and domestic use water for rural and urban population [7]. The main goal of the present study was to assess drinking water quality of Chimdi Lake. For this, lake water samples were collected from three different sites and sample prepared were analyzed for ambient temperature water temperature, Turbidity, Total Dissolved Solid (TDS), Total Suspended Solid (TSS), Conductivity, Hydrogen- ion-concentration ( $\mathrm{pH})$, Dissolved Oxygen (DO), Total hardness (TH), Chloride, Nitrate Nitrogen $\left(\mathrm{NO}_{3}-\mathrm{N}\right)$, Phosphate- phosphorus $\left(\mathrm{PO}_{4}-\mathrm{P}\right)$, Chemical Oxygen Demand (COD), Biological Oxygen Demand (BOD) and fecal coliform.

\section{Materials and Methods}

\subsection{Site Description}

The small and landlocked Kingdom of Nepal extends from 
the highest peak in the world to the plains of the Terai. It lies along the slopes of the Himalaya between China and India with a land area of $147181 \mathrm{sq}$. km being $800 \mathrm{~km}$ from east to west, and from 144 to $240 \mathrm{~km}$ north to south, between $800-$ $880 \mathrm{E}$ and $260-310 \mathrm{~N}$. The country borders India to the East, South and West and China to the North. The elevation ranges from 66 to $8848 \mathrm{~m}$ above sea level. Nepal has many types of wetlands scattered in the Mountain and Terai regions. Its wetlands (approx. 743,500 ha) are particularly important for threatened species [8]. Wetlands provide homes for a huge diversity of wildlife: birds, mammals, fish, frogs, insects and plants [9].

Chimdi Lake (Birju Tal) is located in Chimdi Village Development Committee of Sunsari district of Nepal; $15 \mathrm{~km}$ west from Biratnagar submetropolitan city of Morang district. It has an area of about 101.6 hectare. Its geographical coordinates are $87^{\circ} 10^{\prime} 51.3^{\prime \prime}$ E longitude and 26 $29 ' 23.5^{\prime \prime} \mathrm{N}$ latitude. It is situated at an elevation of $70 \mathrm{~m}$ above mean sea level [10].

\subsection{Methodology}

The physico-chemical and microbiological analysis of water was done on December 15; 2016 (post-monsoon). Water samples were collected between 9 AM to $11 \mathrm{am}$ from the three different representative sites and were brought to the laboratory in $2.5 \mathrm{~L}$ plastic container. Water samples were collected in polyethylene plastic bottles rinsed three times with distilled water for laboratory analysis.

Temperature, $\mathrm{pH}, \mathrm{EC}$ and TDS were detected using a multi-parameter water quality monitoring instrument(HANNA), Dissolved Oxygen(DO) was determined by Modified Winkler Method and free carbon dioxide $\left(\mathrm{FCO}_{2}\right)$ was calculated by Phenolphthalein indicator method on the spot. Likewise, Total hardness (TH) was measured by EDTA (Ethelenediamine tetra acitic acid) method, Turbidity was measured by Digital Nepthelo turbidity meter-132(Systronic), Chloride by using Volhard argentmetric method, Nitrate - Nitrogen $\left(\mathrm{NO}_{3}-\mathrm{N}\right)$ by Phenol Disulfonic Acid Method, Phosphate- phosphorus $\left(\mathrm{PO}_{4}-\mathrm{P}\right)$ by Stannous Chloride Method, Total Dissolved Solid (TDS), Total Suspended Solid (TSS), Chemical Oxygen Demand (COD) Biological Oxygen Demand (BOD) along with fecal coliform (by Membrane filter Technique) were measured in the laboratory by standards prescribed by APHA.

All the sample collection techniques, quality control technique and analytical methods were followed by using Standard Methods for the Examination of Water and Wastewater [11]. The result was tabulated and compared to the guide line for drinking water given by WHO [12].

\section{Result and Discussion}

All the results for physicochemical and microbiological parameters are enumerated in the Table-1 whereas their graphic representations are given in the Fig. -2 and Fig.-3 respectively.

\subsection{Temperature (Air and Water) and Turbidity}

Air temperature recorded was $24^{\circ} \mathrm{C}, 25^{\circ} \mathrm{C}$ and $25^{\circ} \mathrm{C}$ from Site I, Site II and Site III respectively and the average temperature was $24.66^{\circ} \mathrm{C}$. Water temperature was $22^{\circ} \mathrm{C}$ from all the sites.

Clear water contains low turbidity level while muddy water contains high turbidity level. The Turbidity of the lake water was 32.4, 31.5 NTU, and 31.8 NTU from the site I to III respectively and average value was $31.9 \mathrm{NTU}$ which crossed the permissible limit. The turbidity value is influenced by amount of total solids, plankton density, suspended materials and various human activities.

\subsection{Total Dissolved Solid (TDS) and Total Suspended Solid (TSS)}

The value of Total Dissolved Solid was $189.2 \mathrm{mg} / \mathrm{L}, 227.3$ $\mathrm{mg} / \mathrm{L}$ and $220.0 \mathrm{mg} / \mathrm{L}$ from the site I to III respectively and average value was $212.166 \mathrm{mg} / \mathrm{l}$ which was under the permissible limit. Similarly, the value of Total Suspended Solids was $187.1 \mathrm{mg} / \mathrm{L}, 226.21 \mathrm{mg} / \mathrm{L}$ and $219.23 \mathrm{mg} / \mathrm{L}$ from the site I to III respectively and average value was 210.846 $\mathrm{mg} / \mathrm{L}$ which was crossed the tolerance limit.

\subsection{Electrical Conductivity and Hydrogen- Ion-Concentration (pH)}

It is a measure of the ability of an aqueous solution to carry an electric current. It depends on the presence of ions, on their total concentration, mobility and temperature of measurement. Higher value of conductivity shows higher concentration of dissolved ions. E. Conductivity of the lake water was recorded $312.2 \mu \mathrm{s}, 377.8 \mu$ s and $365.6 \mu$ s from the site I to III respectively and the average value was 351.866 $\mu \mathrm{s}$ which is under the WHO guideline.

The chemical condition of normal water is reflected by its pH. $\mathrm{pH}$ plays an important role on the biotic life of a lentic and lotic system. The fluctuation in $\mathrm{pH}$ is mostly due to diurnal interplay of photosynthesis and respiratory processes of animal and plant communities. $\mathrm{pH}$ was recorded 7.5,7.0 and 7.2 from Site I, II and III respectively and average $\mathrm{pH}$ was 7.23 which is under the permissible limit. The $\mathrm{pH}$ of waters varies with the geological nature of the source and the presence of dissolved solids.

\subsection{Dissolved Oxygen and Total Hardness (TH)}

Dissolved oxygen has the most significant role in natural waters among all the chemical substances. The amount of dissolved oxygen in Chimdi lake was found to be ranged 5.6 $\mathrm{mg} / \mathrm{L}, 9.6 \mathrm{mg} / \mathrm{L}$ and $6.8 \mathrm{mg} / \mathrm{L}$ from the sites I to III respectively. The minimum range is $5 \mathrm{mg} / \mathrm{L}$ for drinking water.

The hardness of water is not pollution parameter but indicates water quality mainly in terms of $\mathrm{Ca} 2+$ and $\mathrm{Mg} 2+$ expressed as $\mathrm{CaCO}_{3}$ [13]. Hardness is the indication of suitability of its use in washing and domestic purpose. The hardness in water is due to presence of divalent metallic ions, 
the principal ones are calcium and magnesium. Total hardness was from $204 \mathrm{mg} / \mathrm{L}, 178 \mathrm{mg} / \mathrm{L}$ and $179 \mathrm{mg} / \mathrm{L}$ from site I to site III respectively and the average TH was $187 \mathrm{mg} / \mathrm{l}$ which is more than permissible limit.

\subsection{Chloride}

Chloride content in water may be due to the minerals like mica, apatite and from the liquid inclusions through the igneous rocks [14]. The main concentration of chloride in lakes and pond were due to fecal deposition and household sewage. It is considered as the pollution indicator when present in high concentration. Chloride values recorded $12.99,7.99$ and $5.98 \mathrm{mg} / \mathrm{L}$, from the site I to III respectively and average value was $8.986 \mathrm{mg} / \mathrm{L}$ which was below the permissible limit.

\subsection{Nitrate - Nitrogen $\left(\mathrm{NO}_{3}-\mathrm{N}\right)$}

Nitrate is important nutritional factor in any water body that indicates the rate of eutrophication in the system. $\mathrm{NO}_{3}-\mathrm{N}$ is incorporated in water bodies from natural sources like sewage, household runoff, and runoff from agricultural fields. Nitrogen content of the lake water was $0.065 \mathrm{mg} / \mathrm{L}$, $0.050 \mathrm{mg} / \mathrm{L}$ and $0.053 \mathrm{mg} / \mathrm{L}$ from the site I to III respectively and the average value was $0.053 \mathrm{mg} / \mathrm{L}$ which is under the permissible limit.

\subsection{Phosphate- Phosphorus $\left(\mathrm{PO}_{4}-\mathrm{P}\right)$}

Phosphorus acts as growth limiting factor and is one of the basic nutrients for plants and microorganisms. The concentration of PO4-P in the lake water was $0.129 \mathrm{mg} / \mathrm{L}$, 0.038 and $0.131 \mathrm{mg} / \mathrm{L}$ from the site I to III respectively and the average value was $0.099 \mathrm{mg} / \mathrm{L}$ which was under the permissible limit. It is a pollution indicator, as its higher amount causes eutrophication in freshwater and it acts as growth limiting factor and is an important nutrient for microorganisms.

\subsection{Chemical Oxygen Demand (COD) and Biological Oxygen Demand (BOD)}

Chemical Oxygen Demand is the amount of oxygen required for the oxidation of chemical wastes. COD values recorded was $87.8,80.1 \mathrm{mg} / \mathrm{L}$ and $82.4 \mathrm{mg} / \mathrm{L}$ from the site I to III respectively and the average value was $83.433 \mathrm{mg} / \mathrm{L}$ which was above the tolerance limit.

Biological Oxygen Demand is the measure of degradable organic material present in a water sample, and is the amount of oxygen required by the micro-organisms in stabilizing the biologically degradable organic matter under aerobic conditions. BOD values recorded from the Sites I to III were $1.8 \mathrm{mg} / \mathrm{L}, 2.32 \mathrm{mg} / \mathrm{L}$ and $1.6 \mathrm{mg} / \mathrm{L}$ respectively and the average value was $1.906 \mathrm{mg} / \mathrm{L}$ which was under the tolerance limit.

\subsection{Microbiological Examination}

Fecal coliform was found in all three stations, which show that water is contaminated with human excreta and not suitable for drinking purpose. The presence of fecal coliform recorded in the water samples were $170 \mathrm{MPN} / 100 \mathrm{ml}, 220$ MPN/100 $\mathrm{ml}$ and $380 \mathrm{MPN} / 100 \mathrm{ml}$ from the site I to III respectively and the average value was $256.66 \mathrm{MPN} / 100 \mathrm{ml}$ which was essentially polluted.

Table 1. Physico-chemical and microbiological characteristics of water of Chimdi Lake of Sunsari District, Nepal (Post-monsoon, 2016).

\begin{tabular}{|c|c|c|c|c|c|c|c|}
\hline \multirow{2}{*}{ SI.No. } & \multirow{2}{*}{ Parameters } & \multirow{2}{*}{ Units } & \multicolumn{4}{|c|}{ Post-monsoon (2016) } & \multirow{2}{*}{ WHO Guideline } \\
\hline & & & Site I & Site II & Site III & Mean & \\
\hline 1 & Water depth & (ft.) & 3.5 & 6 & 4 & 4.5 & - \\
\hline 2 & Ambient Temp. & $\left({ }^{\circ} \mathrm{C}\right)$ & 24 & 25 & 25 & 24.66 & - \\
\hline 3 & Water Temp. & $\left({ }^{\circ} \mathrm{C}\right)$ & 23 & 23 & 23 & 23.0 & $22.25^{\circ} \mathrm{C}$ \\
\hline 4 & Turbidity & (NTU) & 32.4 & 31.5 & 31.8 & 31.9 & 1.5 \\
\hline 5 & TDS & $(\mathrm{mg} / \mathrm{L})$ & 189.2 & 227.3 & 220.0 & 212.166 & 1200 \\
\hline 6 & TSS & $(\mathrm{mg} / \mathrm{L})$ & 187.1 & 226.21 & 219.23 & 210.846 & 25 \\
\hline 7 & Conductivity & $(\mu \mathrm{s})$ & 312.2 & 377.8 & 365.6 & 351.866 & 1000 \\
\hline 8 & $\mathrm{pH}$ & & 7.5 & 7 & 7.2 & 7.233 & $6-5-8.5$ \\
\hline 9 & DO & $(\mathrm{mg} / \mathrm{L})$ & 5.6 & 9.6 & 6.8 & 7.333 & 5 \\
\hline 10 & $\mathrm{TH}$ & $(\mathrm{mg} / \mathrm{L})$ & 204 & 178 & 179 & 187 & $<180$ \\
\hline 11 & $\mathrm{Cl}^{-}(\mathrm{mg} / \mathrm{L})$ & & 12.99 & 7.99 & 5.98 & 8.986 & 200 \\
\hline 12 & $\mathrm{NO}_{3}-\mathrm{N}$ & $(\mathrm{mg} / \mathrm{L})$ & 0.065 & 0.050 & 0.045 & 0.053 & 50 \\
\hline 13 & $\mathrm{PO}_{4}-\mathrm{P}$ & $(\mathrm{mg} / \mathrm{L})$ & 0.129 & 0.038 & 0.131 & 0.099 & 14 \\
\hline 14 & COD & $(\mathrm{mg} / \mathrm{L})$ & 87.8 & 80.1 & 82.4 & 83.433 & 40 \\
\hline 15 & BOD & $(\mathrm{mg} / \mathrm{L})$ & 1.8 & 2.32 & 1.6 & 1.906 & 5 \\
\hline 16 & F. Coliform & $(\mathrm{MPN} / 100 \mathrm{ml})$ & 170 & 220 & 380 & 256.66 & Nil \\
\hline
\end{tabular}

$\mathrm{TDS}=$ Total Dissolve Solid, TSS $=$ Total Suspended Solid, DO= Dissolved Oxygen, $\mathrm{TH}=$ Total Hardness, $\mathrm{Cl}^{-}=\mathrm{Chloride}, \mathrm{PO}_{4}-\mathrm{P}=\mathrm{Phosphate}^{-}$phosphorus, $\mathrm{NO}_{3}-\mathrm{N}=$ Nitrate - nitrogen, $\mathrm{BOD}=$ Biological Oxygen Demand, COD $=$ Chemical Oxygen Demand. (Bold numbers indicate the crossed limit of WHO guide line) 


\section{Physicochemical Resuls}

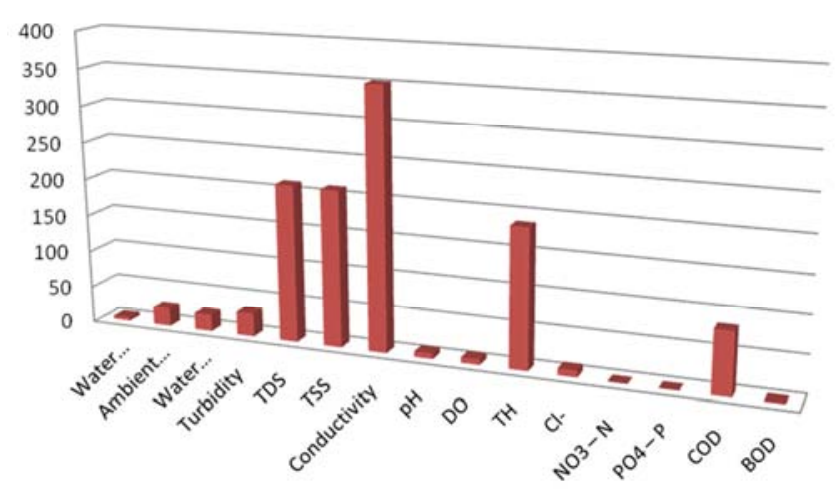

Figure 1. Physico-chemical characteristics of water of Chimdi Wetland of Sunsari District, Nepal (Post-monsoon, 2016).

\section{Fecal coliform (MPN/100 ml)}

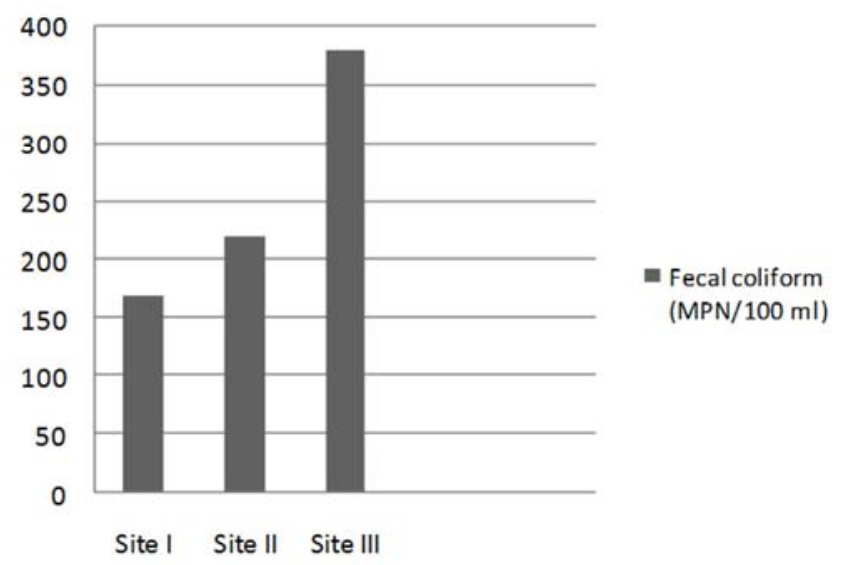

Figure 2. Fecal coliform from water of Chimdi Wetland of Sunsari District, Nepal (Post-monsoon, 2016).

\section{Conclusion}

The present study disclosed the physicochemical and bacteriological contamination of Chimdi lake of Sunsari district, Nepal in post-monsoon season. From the overall assessments of the present work, a unique finding was the presence of some pollutants, such as turbidity (31.9 NTU). TSS (210.846 mg/L), TH (187 mg/L) and COD (83.433 $\mathrm{mg} / \mathrm{L}$ ) were found to be crossed the permissible limit. The findings indicate that the sites of the studied area are in the threshold of mild pollution. High concentration of nutrients may reflect the corresponding increase in algal activity. Another significant finding of this research which supports the nature of pollution is the presence of biological species $E$. coliform in the water body of the Chimdi Lake. It was observed the bacteria, E. coli is isolated from all water samples. The water from the studied area should not be used for drinking and domestic purposes from the microbial viewpoint, so that this water can only be used for multipurpose by boiling to kill bacteria.

\section{References}

[1] Reid, G. K. and Wood, R. D. 1976. Ecology of Inland Waters and Estuaries. 2nd ed. Van Nostrand, New York. 485 PP.

[2] ADB/ICIMOD. 2006. Environmental Assessment of Nepal, Emerging Issues and Challenges. Asian Development Bank and International Centre for Integrated Mountain Development, Kathmandu. pp: 55-64.

[3] Merz, J., G. Nakarmi, S. K. Shrestha, B. M. Dahal, B. S. Dongol, M. Schaffner, S. Shakya, S. Sharma, and R. Weingartner, 2004, Public water sources in rural catchments of Nepal's middle mountains-issues and constraints, Environmental Management, 34 (1): 26-37.

[4] Sharma, C. K. 1977. River systems of Nepal. Mrs. Sangeeta Sharma, Kathmandu.

[5] Likens GE (ed.) (1985) An Ecosystem Approach to Aquatic Ecology: Mirror Lake and its Environment. New York: Springer-Verlag.

[6] B. Pradhan, "Water Quality Assessment of the Bagmati River and its Tributaries, Kathmandu, Nepal," M. S. The-sis, BokuUniversity, Vienna, 1998.

[7] S. Chandra, A. Singh and P. K. Tomar - "Assessment of Water Quality Values in Porur Lake Chennai, Hussain Sagar Hyderabad and Vihar Lake Mumbai, India", Chem Sci Trans., 1 (3), 508-515, 2012.

[8] DOAD. 1992. National Fisheries Development Plan, 1992/93. Fisheries Development Division, Department of Agriculture Development, HMGN, Kathmandu, Nepal.

[9] Buckton, S. 2007. Managing Wetlands for Sustainable Livelihoods at Koshi Tappu. Danphe. 16 (1/4).

[10] R. Surana1, B. R Subba and K. P Limbu (2007). Avian diversity during rehabilitation stage of Chimdi Lake, Sunsari, Nepal, Our Nature-5: 75-80.

[11] APHA, AWWA \& WEF. 1998. Standard methods for the examination of water and wastewater. American Association of Public Health, American Water Works Association and the Water Pollution Control Federation, American Public health Association, $20^{\text {th }}$ Edition, Washington. D.C. 1268 p.

[12] World Health Organization (WHO).2002. Guidelines for Drinking Water Quality, World Health Organization, Geneve

[13] De, A. K., Environmental chemistry (6 ${ }^{\text {th }}$ edn.). New Delhi, India: New Age International Publishers (232) (2006).

[14] P. K. Das, S. D. Malik, J. Indian Water Resources Soc., 1998, 8 (3), 31-41. 